\title{
Analisis Regresi Spasial pada Indeks Pembangunan Manusia di Provinsi Sumatera Utara Tahun 2020
}

\author{
(Spatial Regression Analysis on the HDI in North Sumatera Province in 2020) \\ Wenny Srimeinda Tarigan \\ Universitas Padjadjaran \\ E-mail: wenny20001@mail.unpad.ac.id
}

\begin{abstract}
ABSTRAK
Indeks Pembangunan Manusia (IPM) di suatu wilayah dipengaruhi oleh IPM di wilayah lain yang berdekatan. Analisis mengenai faktor-faktor yang mempengaruhi IPM dapat dilakukan melalui regresi linier klasik. Tetapi, apabila sudah memperhitungkan lokasi, analisis regresi spasial merupakan metode yang lebih sesuai untuk digunakan. Tujuan penelitian ini adalah melakukan analisis regresi spasial pada IPM di 33 kabupaten/kota Provinsi Sumatera Utara tahun 2020. Model yang digunakan adalah model Spatial Autoregressive (SAR). Nilai $\rho$ yang positif menunjukkan bahwa semakin meningkat nilai IPM dari daerah yang mengelilingi sebuah kabupaten/kota, maka semakin meningkat pula nilai IPM di kabupaten/kota tersebut. Direct effect yang diperoleh adalah -0,5069455 sedangkan indirect effect adalah -0,313711. Persentase penduduk miskin memiliki pengaruh negatif yang signifikan yang artinya peningkatan persentase penduduk miskin akan menyebabkan penurunan IPM. Oleh karena itu, pemerintah disarankan dapat mengambil kebijakan yang tepat dari segi ekonomi khususnya dalam pengentasan kemiskinan sehingga dapat meningkatkan IPM di Provinsi Sumatera Utara.
\end{abstract}

Kata kunci: IPM, kemiskinan, SAR, spasial,

\begin{abstract}
Human Development Index (HDI) in an area is influenced by the HDI in adjacent areas. Analysis of the factors that affect HDI can be done through classical linear regression. However, if it have taken into account the location, the spatial regression analysis is a more suitable method to use. The purpose of this research is to perform a spatial regression analysis on the HDI in 33 district/city of North Sumatera Province in 2020. The model used is Spatial Autoregressive $(S A R)$ model. A positive value of $\rho$ indicates that an increase of the HDI in the area surrounding a district/city will increase the HDI in that district/city. The direct effect obtained is -0.5069455 while the indirect effect is -0.313711 . The percentage of poor people has a significant negative effect, which means that an increase of the percentage of poor people will cause a decrease of the HDI. Therefore, the government is advised to take appropriate policies from an economic perspective, especially in reducing poverty so that it can increase the HDI in North Sumatera Province.
\end{abstract}

Keywords: HDI, poverty, SAR, spatial

\section{PENDAHULUAN}

\section{Latar Belakang}

Pembangunan manusia memiliki peran penting dalam proses pembangunan suatu negara. Pembangunan manusia adalah tentang memperluas kebebasan manusia dan membuka lebih banyak pilihan bagi manusia untuk memilih jalan manusia itu sendiri dalam membentuk pembangunan manusia sesuai dengan nilai-nilai manusia tersebut yang beragam (United Nations Development Programme, 2020). Jika peningkatan kesejahteraan manusia tidak diperhatikan, maka akan membuat suatu negara mengalami ketertinggalan dari negara lain. Oleh sebab itu, pembangunan manusia perlu untuk ditingkatkan. Sebuah peningkatan memerlukan sebuah ukuran dalam perhitungannya. United Nations Development Programme (UNDP) menggunakan tiga dimensi dalam pengukuran pembangunan manusia, yaitu umur panjang, pengetahuan, dan kehidupan yang layak (United Nations Development Programme, 1990). Peningkatan IPM Indonesia dipengaruhi oleh peningkatan IPM kabupaten/kota di Indonesia, salah satunya Provinsi Sumatera Utara.

Indeks Pembangunan Manusia (IPM) di suatu wilayah dipengaruhi oleh IPM di wilayah lain yang berdekatan. Hal ini berdasarkan pada hukum Tobler yang berbunyi "segala sesuatu berhubungan dengan lainnya, tetapi hal-hal yang lebih dekat lebih terkait daripada hal-hal yang jauh" (Jaya \& Andriyana, 2020). Wilayah yang lokasinya berdekatan mempunyai hubungan yang lebih tinggi daripada lokasi yang lokasinya jauh. Analisis mengenai faktor-faktor yang mempengaruhi IPM dapat dilakukan melalui regresi linier klasik. 
Tetapi, apabila sudah memperhitungkan lokasi, analisis regresi spasial merupakan metode yang lebih sesuai untuk digunakan. Regresi spasial merupakan pengembangan dari regresi linier klasik yang didasarkan pada adanya pengaruh lokasi pada data yang dianalisis.

\section{Penelitian Terkait}

Penelitian yang dilakukan oleh Alwi, dkk. pada tahun 2019 menghasilkan bahwa tenaga kesehatan, upah minimum kabupaten, dan angka partisipasi kasar sekolah menengah atas berpengaruh signifikan terhadap IPM Provinsi Jawa Tengah dengan model terbaik yang digunakan adalah SAR (Alwi \& dkk, 2019). Pramesti dan Indrasetianingsih pada tahun 2019 menemukan bahwa persentase penduduk miskin, angka harapan sekolah , dan pengeluaran per kapita berpengaruh signifikan terhadap IPM Provinsi Jawa Timur dengan model terbaik yang digunakan adalah Spatial Error Model (SEM) (Pramesti \& Indrasetianingsih, 2019). Selanjutnya, penelitian yang dilakukan oleh Rosa, dkk. pada tahun 2020 menghasilkan bahwa persentase rumah tangga yang memiliki tempat buang air besar sendiri, persentase kepadatan penduduk, dan persentase penduduk miskin berpengaruh signifikan terhadap IPM Provinsi Jawa Timur dengan model yang digunakan adalah model SAR (Rosa \& dkk., 2020). Novitasari dan Khikmah pada tahun 2019 menemukan bahwa model SAR lebih baik digunakan daripada model SEM pada IPM Provinsi Jawa Tengah (Novitasari \& Khikmah, 2019).

\section{Tujuan Penelitian}

Berdasarkan uraian yang terdapat pada latar belakang, maka tujuan dari penelitian ini adalah untuk melakukan analisis regresi spasial pada IPM Provinsi Sumatera Utara tahun 2020.

\section{METODE}

\section{Data}

Penelitian ini menggunakan data sekunder yang diperoleh dari berbagai hasil survei yang dilakukan oleh Badan Pusat Statistik (BPS) Provinsi Sumatera Utara. Unit observasi pada penelitian ini adalah 33 kabupaten/kota di Provinsi Sumatera Utara. Periode waktu yang digunakan adalah tahun 2020. Variabel dependen yang digunakan dalam penelitian ini adalah IPM sedangkan yang menjadi variabel independen adalah persentase penduduk miskin.

\section{Metode Analisis}

Analisis yang digunakan dalam penelitian ini adalah analisis regresi spasial. Analisis regresi spasial merupakan pengembangan dari analisis regresi yang mengakomodir permasalahan yang timbul pada data spasial. Pada saat data mempunyai komponen lokasi, terdapat dua masalah yang muncul yaitu adanya ketergantungan spasial antar pengamatan (spatial dependence) dan heterogenitas spasial (spatial heterogenity) dalam proses pemodelan (LeSage, 1999). Spatial dependence mengakibatkan terjadinya autokorelasi spasial (spatial autocorrelation) sedangkan spatial heterogenity mengakibatkan varians yang tidak konstan. Beberapa model regresi spasial adalah sebagai berikut:

$>$ Spatial Autoregressive Model (SAR)

Spatial Autoregressive Model (SAR) merupakan model regresi linier yang terjadi karena terdapat ketergantungan nilai variabel dependen pada suatu wilayah dengan wilayah lain. Model umum untuk SAR yaitu (LeSage, 1998):

$\boldsymbol{y}=\rho \boldsymbol{W} \boldsymbol{y}+\boldsymbol{X} \boldsymbol{\beta}+\boldsymbol{\varepsilon}$

$\varepsilon \sim N\left(0, \sigma^{2} I_{n}\right)$

dimana:

$\boldsymbol{y}=$ vektor variabel dependen berukuran $\mathrm{nx} 1$

$\rho=$ koefisien variabel dependen lag spasial

$\boldsymbol{W}=$ matriks bobot spasial

$\boldsymbol{X}=$ matriks variabel independen berukuran $\mathrm{n} \times \mathrm{k}$

$\boldsymbol{\beta}=$ parameter yang mencerminkan pengaruh variabel independen terhadap variasi pada variabel dependen 
Spatial Error Model (SEM)

Spatial Error Model (SEM) merupakan model regresi linier yang terjadi karena terdapat ketergantungan error pada suatu wilayah dengan wilayah lain. Model umum untuk SEM yaitu (LeSage, 1998):

$$
\begin{aligned}
& \boldsymbol{y}=\boldsymbol{X} \boldsymbol{\beta}+\boldsymbol{u} \\
& \boldsymbol{u}=\lambda \boldsymbol{W} \boldsymbol{u}+\boldsymbol{\varepsilon} \\
& \boldsymbol{\varepsilon} \sim N\left(0, \sigma^{2} I_{n}\right) \\
& \text { dimana: } \\
& \boldsymbol{y}=\text { vektor variabel dependen berukuran } \mathrm{nx} 1
\end{aligned}
$$$$
\boldsymbol{X}=\text { matriks variabel independen berukuran } \mathrm{n} \mathrm{k}
$$

$\boldsymbol{\beta}=$ parameter yang mencerminkan pengaruh variabel independen terhadap variasi pada variabel dependen

$\lambda=$ parameter yang merupakan koefisien error korelasi spasial

$\boldsymbol{W}=$ matriks bobot spasial

Tahapan analisis data yang dilakukan yaitu :

1. Analisis deskriptif menggunakan peta tematik

2. Melakukan estimasi parameter dengan model regresi linier klasik

3. Melakukan uji asumsi klasik

4. Menghitung matriks pembobot spasial dengan Queen Contiguity

5. Melakukan uji Moran's I

6. Melakukan uji Lagrange Multiplier

7. Melakukan estimasi parameter dengan model regresi spasial yang terpilih pada uji Lagrange Multiplier

8. Interpretasi model regresi spasial

\section{Matriks Pembobot Spasial}

Matriks pembobot spasial merupakan matriks simetris positif berukuran $\mathrm{n} x \mathrm{n}$ dimana $\mathrm{n}$ adalah jumlah lokasi. Matriks pembobot spasial menunjukkan hubungan antar lokasi. Matriks tersebut diperoleh berdasarkan ketetanggaan (contiguity) dan jarak.

\section{Uji Moran's I}

Ketergantungan antara suatu lokasi dengan lokasi lain yang letaknya berdekatan menyebabkan terjadinya autokorelasi spasial. Salah satu uji yang digunakan dalam pemeriksaan keberadaan autokorelasi spasial secara global yaitu Moran's I yang dapat diperoleh dengan formula sebagai berikut (Grekousis, 2020):

$$
I=\frac{n}{\sum_{i=1}^{n} \sum_{j=1}^{n} w_{i j}} \frac{\sum_{i=1}^{n} \sum_{j=1}^{n} w_{i j}\left(x_{i}-\bar{x}\right)\left(x_{j}-\bar{x}\right)}{\sum_{i=1}^{n}\left(x_{i}-\bar{x}\right)^{2}} .
$$

dimana:

I = global Moran's I

$\mathrm{n}=$ jumlah observasi spasial

$x_{i}=$ variabel observasi ke- $\mathrm{i}$

$x_{j}=$ variabel observasi ke- $\mathrm{j}$

$\bar{x}=$ rata-rata variabel

$w_{i j}=$ bobot spasial antara observasi i dan $\mathrm{j}$

Moran's I memiliki nilai yang berkisar antara $-1<$ I $<1$. Adapun hipotesis pengujian yang dilakukan yaitu:

$H_{0}: \mathrm{I}=\mathrm{E}(\mathrm{I})$ (tidak terdapat autokorelasi spasial)

$H_{1}: \mathrm{I} \neq \mathrm{E}(\mathrm{I})$ (terdapat autokorelasi spasial)

\section{Uji Lagrange Multiplier}

\section{Uji Lagrange Multiplier Lag}

Uji Lagrange Multiplier Lag dilakukan dalam pemeriksaan keberadaan autokorelasi spasial lag pada variabel dependen. Hipotesis pengujian yang dilakukan yaitu:

$H_{0}: \rho=0$ (tidak terdapat autokorelasi spasial lag pada variabel dependen)

$H_{1}: \rho \neq 0$ (terdapat autokorelasi spasial lag pada variabel dependen) 


\section{Uji Lagrange Multiplier Error}

Uji Lagrange Multiplier Error dilakukan dalam pemeriksaan keberadaan autokorelasi spasial pada error. Hipotesis pengujian yang dilakukan yaitu:

$H_{0}: \lambda=0$ (tidak terdapat autokorelasi spasial pada error)

$H_{1}: \lambda \neq 0$ (terdapat autokorelasi spasial pada error)

\section{HASIL DAN PEMBAHASAN}

\section{Analisis Deskriptif}

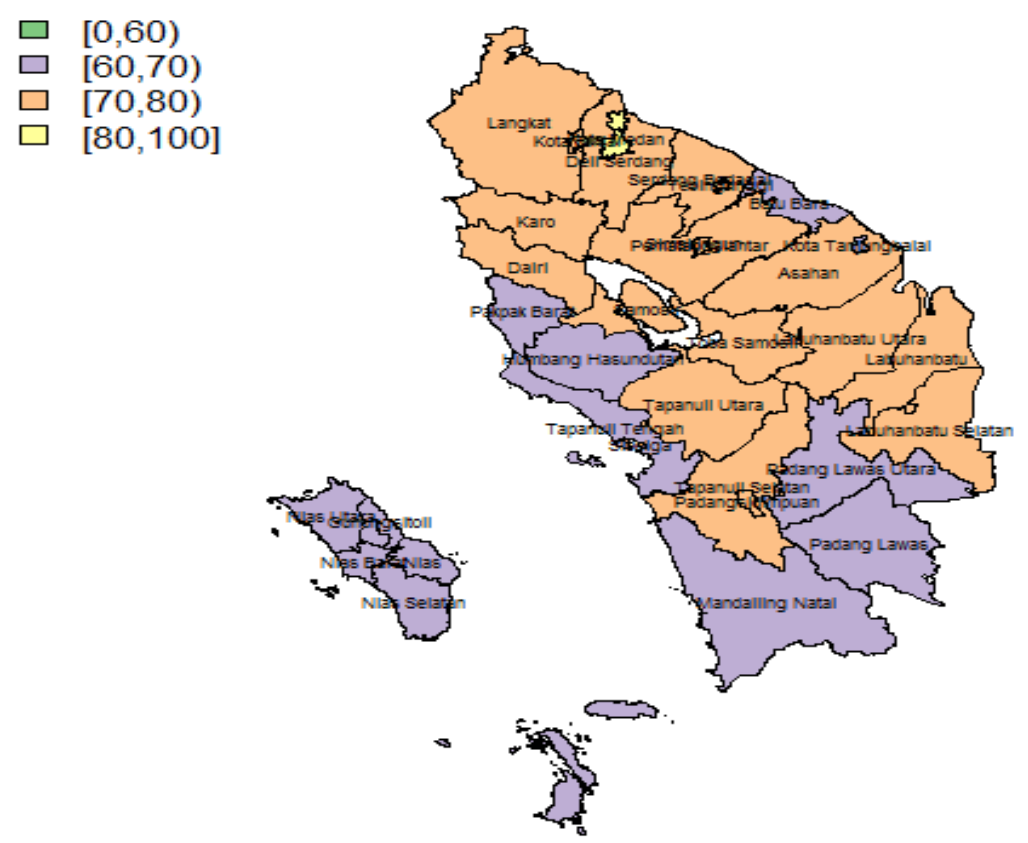

Gambar 1. IPM Provinsi Sumatera Utara Tahun 2020

Gambaran umum IPM Provinsi Sumatera Utara tahun 2020 dapat dilihat pada Gambar 1. Menurut BPS, IPM dapat dikelompokkan menjadi 4 kategori yaitu kategori rendah, sedang, tinggi, dan sangat tinggi. Dari gambar tersebut terlihat bahwa tidak ada IPM kabupaten/kota di provinsi Sumatera Utara yang tergolong rendah pada tahun 2020. IPM tertinggi dimiliki oleh kota Medan. Sebagian besar kabupaten/kota di Provinsi Sumatera Utara yang lokasinya berdekatan memiliki warna yang sama. Fenomena ini menunjukkan bahwa kabupaten/kota yang berdekatan memiliki nilai IPM yang hampir sama. Dengan demikian, dapat dikatakan terdapat indikasi bahwa terjadi autokorelasi spasial.

\section{Model Regresi Linier Klasik}

Hasil estimasi parameter dengan model linier dapat dilihat pada persamaan berikut: $\hat{y}_{i}=78,57-0,72 x_{i}$

Model tersebut memiliki $R^{2}$ Adjusted sebesar 0,5327. Nilai tersebut menyatakan bahwa persentase penduduk miskin dapat menjelaskan varians IPM sebesar 53,27\% dan sisanya dijelaskan oleh variabel lain yang belum masuk dalam model tersebut. Selanjutnya dilakukan uji asumsi klasik. Hasil uji asumsi klasik dengan $\alpha=0,1$ dapat dilihat pada tabel berikut:

Tabel 1. Hasil Uji Asumsi Klasik

\begin{tabular}{lcll}
\hline \multicolumn{1}{c}{ Asumsi } & P-value & Keputusan & \multicolumn{1}{c}{ Kesimpulan } \\
\hline Linieritas & 0,4412 & Terima $H_{0}$ & Model linier \\
Normalitas & 0,4732 & Terima $H_{0}$ & Error berdistribusi normal \\
Homoskedastisitas & 0,7038 & Terima $H_{0}$ & Error model memiliki varians yang konstan \\
\hline
\end{tabular}

Dari Tabel 1. dapat dilihat bahwa asumsi klasik yaitu linieritas, normalitas, dan homoskedastisitas sudah terpenuhi. 


\section{Moran's I}

Pemeriksaan keberadaan autokorelasi spasial digunakan dengan nilai Moran's I. Penelitian ini melakukan uji signifikansi pada $\alpha=0,1$. Penghitungan matriks pembobot spasial perlu dilakukan terlebih dahulu untuk memperoleh nilai Moran's I. Matriks pembobot spasial yang digunakan adalah Queen Contiguity (persinggungan sisi-sudut).

Dengan menggunakan Queen Contiguity, diperoleh nilai statistik uji Moran's I sebagai berikut:

$$
Z_{\text {hitung }}=\frac{I-E(I)}{\sqrt{\operatorname{Var}(I)}}=\frac{0,5834-(-0,0312)}{\sqrt{0,0185}}=4,5186
$$

Berdasarkan penghitungan tersebut, $Z_{\text {hitung }}=4,5186>Z_{\alpha / 2}=1,64$ maka diperoleh keputusan tolak $H_{0}$ yang artinya terjadi autokorelasi spasial pada IPM di kabupaten/kota Provinsi Sumatera Utara tahun 2020. Nilai I yang lebih besar dari E(I) menyatakan bahwa autokorelasi spasial yang terjadi adalah autokorelasi positif. Signifikansi autokorelasi spasial secara lokal dapat dilihat melalui Local Indicator of Spatial Autocorrelation (LISA) yang ditunjukkan pada Gambar 2.

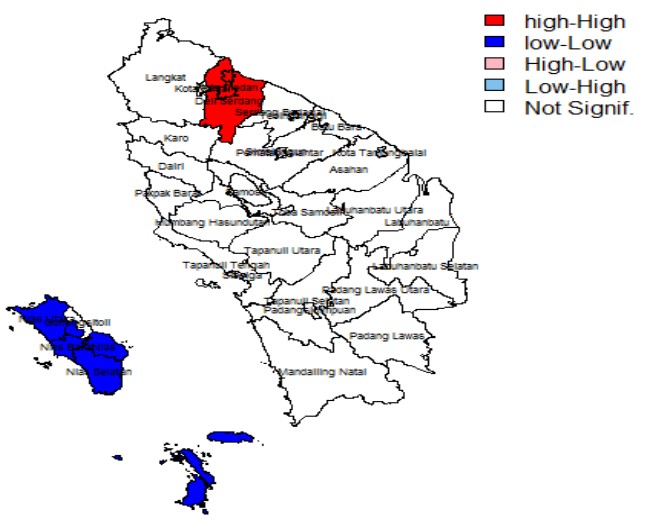

Gambar 2. Local Indicator of Spatial Autocorrelation (LISA)

Dari Gambar 2. dapat dilihat bahwa kabupaten/kota yang memiliki IPM kategori tinggi berdekatan dengan kabupaten/kota yang memiliki IPM kategori tinggi pula (High-High) dan kabupaten/kota yang memiliki IPM kategori sedang berdekatan dengan kabupaten/kota yang memiliki IPM kategori sedang pula (Low-Low). Hal ini sesuai dengan hasil uji Moran's I yang telah diperoleh sebelumnya yaitu terdapat autokorelasi spasial positif yang berarti bahwa kabupaten/kota yang lokasinya berdekatan memiliki nilai IPM yang cenderung sama.

\section{Lagrange Multiplier}

Uji Lagrange Multiplier digunakan untuk memilih model regresi spasial yang sesuai. Hasil uji Lagrange Multiplier pada lag dan error dengan $\alpha=0,1$ dapat dilihat pada Tabel 2 .

Tabel 2. Hasil uji Lagrange Multiplier

\begin{tabular}{ccccc}
\hline Uji & Nilai Statistik & P-value & Keputusan & Kesimpulan \\
\hline$L M_{\text {lag }}$ & 2,83688 & 0,09212 & Tolak $H_{0}$ & Terdapat autokorelasi spasial lag pada variabel dependen \\
$L M_{\text {error }}$ & 0,35111 & 0,55349 & Terima $H_{0}$ & Tidak terdapat autokorelasi spasial pada error \\
\hline
\end{tabular}

Dari Tabel 2. dapat disimpulkan bahwa terdapat autokorelasi spasial lag pada variabel dependen, sehingga model regresi spasial yang dapat digunakan pada penelitian ini adalah Spatial Autoregressive Model (SAR).

\section{Model SAR}

Hasil estimasi parameter dengan model SAR dapat dilihat pada persamaan berikut:

$\hat{y}_{i}=0,41651 \boldsymbol{W} \boldsymbol{y}+46.68980-0,47884 x_{i}$

Variabel persentase penduduk miskin signifikan berpengaruh terhadap IPM karena nilai p-value $=0,0005<\alpha$ $=0,1$. Persentase penduduk miskin memiliki pengaruh negatif yang artinya peningkatan persentase penduduk miskin akan menyebabkan penurunan IPM. Nilai $\rho$ yang positif menunjukkan bahwa semakin meningkat nilai IPM dari daerah yang mengelilingi sebuah kabupaten/kota, maka semakin meningkat pula nilai IPM di kabupaten/kota tersebut. Nilai AIC yang diperoleh dari model SAR adalah 170,65 sedangkan nilai AIC yang 
diperoleh dari model linier klasik adalah 173,28. Dengan demikian, dapat disimpulkan bahwa model terbaik adalah model SAR karena memiliki nilai AIC terkecil.

\section{Spillover Effect}

Pada model SAR terdapat spillover effect yang merupakan efek dari perubahan variabel independen (persentase penduduk miskin) pada kabupaten/kota tertentu terhadap nilai IPM kabupaten/kota itu sendiri (direct effect) dan juga terhadap nilai IPM kabupaten/kota lain (indirect effect). Spillover effect yang diperoleh adalah sebagai berikut:

Tabel 3. Spillover Effect

\begin{tabular}{cc}
\hline Efek & Nilai \\
\hline Direct Effect & $-0,5069455$ \\
Indirect Effect & $-0,313711$ \\
Total & $-0,8206566$ \\
\hline
\end{tabular}

Dari Tabel 3. dapat dilihat bahwa persentase penduduk miskin memiliki efek yang negatif baik itu secara langsung (direct effect) maupun tidak langsung (indirect effect). Hal ini menunjukkan bahwa apabila persentase penduduk miskin di suatu kabupaten/kota meningkat sebesar 1\%, maka nilai IPM akan mengalami penurunan sebesar 0,5069455 pada kabupaten/kota tersebut dan sebesar 0,313711 pada kabupaten/kota lain.

\section{KESIMPULAN}

Model yang digunakan adalah model SAR karena terdapat autokorelasi spasial lag pada variabel dependen. Nilai AIC pada SAR sebesar 170,65 lebih kecil daripada nilai AIC pada model linier klasik yaitu sebesar 173,28, sehingga model SAR lebih baik digunakan pada IPM provinsi Sumatera Utara tahun 2020. Persentase penduduk miskin memiliki pengaruh negatif yang signifikan yang artinya peningkatan persentase penduduk miskin akan menyebabkan penurunan IPM. Nilai $\rho$ yang positif menunjukkan bahwa semakin meningkat nilai IPM dari daerah yang mengelilingi sebuah kabupaten/kota, maka semakin meningkat pula nilai IPM di kabupaten/kota tersebut.

Saran yang dapat diberikan dari hasil penelitian ini adalah agar pemerintah dapat mengambil kebijakan yang tepat dari segi ekonomi khususnya dalam pengentasan kemiskinan sehingga dapat meningkatkan angka IPM di provinsi Sumatera Utara.

\section{DAFTAR PUSTAKA}

Alwi,W., dkk. (2019). Pemodelan Indeks Pembangunan Manusia di Provinsi Jawa Tengah Tahun 2017 Menggunakan Analisis Regresi Spasial. Jurnal Ilmiah Matematika dan Pendidikan Matematika (JMP), $11(1), 45-58$.

Grekousis, G. (2020). Spatial Analysis Methods and Practice. Cambridge University Press.

Jaya, I.G.N.M \& Andriyana,Y. (2020). Analisis Data Spasial Perspektif Bayesian. Alqaprint Jatinangor.

LeSage, J.P. (1999). The Theory and Practice of Spatial Econometrics. Department of Economics University of Toledo.

LeSage, J.P. (1998). Spatial Econometrics. Department of Economics University of Toledo.

Novitasari, D. \& Khikmah, L. (2019). Penerapan Model Regresi Spasial pada Indeks Pembangunan Manusia (IPM) di Jawa Tengah. Statistika, 19 (2), 123-134.

Pramesti, W. \& Indrasetianingsih, A.(2019). Analisis Regresi Spatial Error Model untuk Mengetahui FaktorFaktor yang Mempengaruhi Indeks Pembangunan Manusia Provinsi Jawa Timur. Seminar Nasional Hasil Riset dan Pengabdian ke-II. UNIPA Surabaya. Surabaya.

Rosa, M., dkk. (2020). Pemodelan Indeks Pembangunan Manusia Menggunakan Analisis Regresi Spasial di Provinsi Jawa Timur. Jurnal Matematika UNAND, 9 (4), 347-356.

United Nations Development Programme. (1990). Human Development Report 1990. Oxford University Press. New York.

United Nations Development Programme. (2020). Human Development Report 2020. United Nations Development Programme. New York. 